\title{
Hydrogeochemical Process and Quality Assessment of Surface Water Around Fuli Abandoned Quarries Area, Northern Anhui Province, China
}

\author{
Jiying $\mathrm{Xu}^{1}$, Herong Gui ${ }^{*}$, Jiayu Chen ${ }^{2}$, Chen $\mathrm{Li}^{2}$, Ye $\mathrm{Li}^{3}$, Chengzhou Zhao ${ }^{3}$, Yan $\mathrm{Guo}^{1}$ \\ ${ }^{1}$ School of Resources and Civil Engineering, Suzhou University, Suzhou, 234000 Anhui, China \\ ${ }^{2}$ School of Earth and Environment, Anhui University of Science and Technology, Huainan, 232001, Anhui, China \\ ${ }^{3}$ Huaibei Mining Co. Ltd, Huaibei, 235000, Anhui, China
}

Received: 29 April 2021

Accepted: 18 September 2021

\begin{abstract}
Surface water is an indispensable water resource of drinking and irrigation, which plays important role on human health and quantity of grain production. Hydrogeochemical process as well as quality assessment of 31 representative surface water samples from 3 typical lakes around Fuli abandoned quarries area were carried out. The cation is dominated by $\mathrm{Ca}^{2+}$ and $\mathrm{Mg}^{2+}$, while the anion is dominated by $\mathrm{HCO}_{3}^{-}$and $\mathrm{SO}_{4}{ }^{2-}$. The two leading hydrochemical type are $\mathrm{SO}_{4} \mathrm{HCO}_{3}-\mathrm{Ca} \cdot \mathrm{Mg}(100 \%)$ in No. 1 lake, wheres $\mathrm{HCO}_{3} \mathrm{SO}_{4-} \mathrm{Ca} . \mathrm{Mg}(88.24 \%)$ and $\mathrm{SO}_{4} \mathrm{HCO}_{3}$-Ca.Mg (11.76\%) of No.2 and No.3 lake. The chemical composition of No.1 lake are mainly controlled by carbonate dissolution and ion-exchange, the chemical composition of No.2 and No.3 lake is mainly influenced by both ion-exchange and dissolution of carbonate and silicate minerals, among which rock weathering is the most important factor. The recharging of the lakes is mainly derived from atmospheric precipitation with the existence of evaporation. The surface water in the study area, in general, is suitable for drinking and irrigation. The outcomes of this research provide a better understanding of hydrochemical mechanism of surface water around quarries, and it will help to improve management and sustainable utilization of water resources for local government.
\end{abstract}

Keywords: hydrogeochemistry, abandoned quarries, surface water, isotopes, water quality

\section{Introduction}

Water is a natural resource for human living, especially for drinking and irrigation. The irrational utilization of water resources leads to degradation of its quality and lowering of water table. The surface

*e-mail: guiherong@163.com water around mining area is widely useful for industrial and domestic demand [1-2]. The mining water are facing two issues of change in water quality and decline of water table in many parts of the World [3-6]. Water quality is the key factor for human health and quantity of grains by influencing on soils, biology and environment. Water quality assessment is usually on the basis of hydrogeochemical analysis [7]. In light of sustainable management of water resources, 
understanding the dominant processes that govern water hydrogeochemical evolution and quality assessment is critically needed.

It is generally believed that the hydrogeochemical process of water in mining area is typically affected by natural factors including the composition of rain water, geological structure, mineralogy and waterrock interaction [8]. In addition to natural processes, mining activities can also strongly influence the hydrogeochemical characteristic of water [9]. Numerous studies have been show that major ion concentrations and stable isotopic composition in mining water are effectively used to understand recharge and flow, formation mechanisms, interaction between water and surrounding rock [10-12]. The water quality assessment are also carried out for drinking and agriculture. World Health Organization (WHO) published the guidelines for drinking water to protect public health [13]. The guidelines for agriculture is provided by the Food and Agriculture Organization of the United Nations (FAO) [14]. Salinity and sodium hazard indicators are widely used as a criterion to find the suitable of irrigation waters [15]. A large number of studies have been carried out on the hydrogeochemistry and water quality evaluation of water in cities, rural areas and coal mines, but for abandoned quarries remains unclear, which need to be addressed urgently.
Hence, the objective of this study are as follow: (1) to determine the dominant geochemical processes that controlling the chemical component of surface water around abandoned quarries area (2) to identify the sources of surface water (3) to assess the water quality for drinking and irrigation. The conclusion of this research will provide a better understanding of the mechanism of surface water around quarries, and improve management and sustainable utilization of water resources for local government.

\section{Materials and Methods}

\section{Study Area}

Fuli abandoned quarries are located $20 \mathrm{~km}$ north to Suzhou city in Anhui province, China. Its geographical coordinates are 116 $52^{\prime} 12^{\prime \prime}-116^{\circ} 59^{\prime} 11^{\prime \prime}$ north and 3343'56"-33'48'5" east. The abandoned quarries covers an area of $30.27 \mathrm{~km}^{2}$ in the northern hilly area of Huaibei plain (Fig. 1). The terrain is high in the north and low in the south. The elevation of abandoned quarries range from $55.58 \mathrm{~m}$ to $185.24 \mathrm{~m}$, with an average of $111.32 \mathrm{~m}$.

The climate of the study area belongs to warm temperate zone and semi-humid monsoon section,

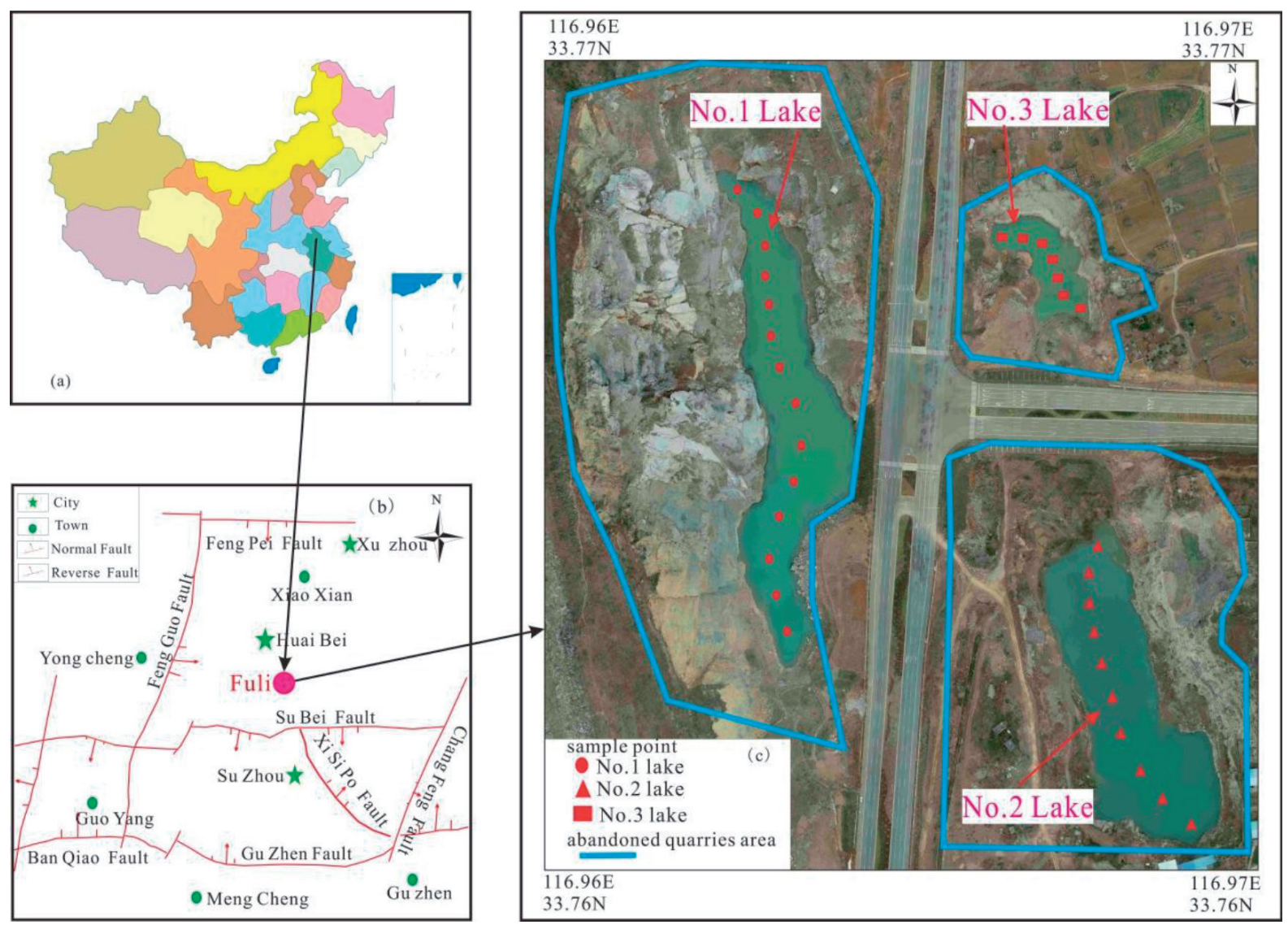

Fig. 1. Regional geographic location and distribution of sampling points. a) China; b) Structural map of Huaibei Area; c) the location of sampling sites. 
characterized by mild climate and four distinct seasons, with an average annual temperature of $14.5^{\circ} \mathrm{C}$, and an average annual rainfall around $774 \mathrm{~mm}$.

Geologically, the quarries area is located in the north side of Su Bei Fault and the middle part of XuzhouSuzhou structure, which is a monoclinic structure with NE strike, SE dip and $28^{\circ}$ dip. The exposed strata include dolomitic limestone of the upper Cambrian Changshan formation and brownish yellow, grayish yellow and brownish red clay of Panji formation of Mid-Pleistocene [16].

The quarries belong to stone mine, which play an important role for building and road construction. Due to local environmental protection policy, the Fuli quarries were closed in 2001 and turn into abandoned quarries. The result of open-pit mining is mainly in the damage of mountains and ecological vegetation. The original landform is razed to the ground, or forming a lake. As the quarries are located on the hillside, its surface water system is not developed. Hence, the lake is the main composition of surface water in the quarries area. The water level is controlled by rainfall, high in summer and low in winter, with an average depth of $13.40 \mathrm{~m}$

\section{Sample Collection and Processing}

A total of 31 water samples were collected from 3 typical lakes around Fuli abandoned quarries area during the dry season (November ) of 2020, as shown in Fig. 1. The samples were collected by pre-cleaned HDPE bottles. Before collection, the samples were moistened with distilled water for 2 times, then washed again with water samples for 3 times and were sealed with sealing film on site. After that, the collection samples were immediately filtered with $0.45 \mu \mathrm{m}$ filter paper within $24 \mathrm{~h}$ after collected, and the water samples were kept under low temperature conditions.

The conductivity (EC), $\mathrm{pH}$, and total soluble solids (TDS) of all samples were obtained in the field by portable devices (ST20R, ST20 and ST20T-B) from OHAUS (Shanghai, China). The contents of main cations $\left(\mathrm{Na}^{+}, \mathrm{K}^{+}, \mathrm{Ca}^{2+}, \mathrm{Mg}^{2+}\right)$ and main anions $\left(\mathrm{SO}_{4}^{2}\right.$, $\mathrm{Cl}^{-}$) were measured by Ion chromatograph (ICS-600900 , USA). The contents of $\mathrm{CO}_{3}{ }^{2-}$ and $\mathrm{HCO}_{3}{ }^{-}$were determined by acid-base titration (analysis error of anion and cation was controlled within 5\%). The stable isotopes of hydrogen and oxygen $\left(\delta \mathrm{D}, \delta^{18} \mathrm{O}\right)$ were measured by isotope analyzer (LGR-LWIA-45EP, USA). The measurement accuracy of $\delta \mathrm{D}$ and $\delta^{18} \mathrm{O}$ was $1.0 \%$ and $0.2 \%$ respectively.

Before all samples were tested, the stability of the test instrument was tested with standard samples, and parallel samples were set, and the relative deviation of parallel samples was less than 5\%. Moreover, $20 \%$ of the water samples were re-tested. The errors between the outcomes of two analysis were less than $10 \%$.

\section{Results and Discussion}

\section{Hydrochemical Characteristics}

Geochemical data for surface water samples from No.1, No. 2, No. 3 lake are listed in Table 1 and Fig. 2. The temperature of the samples range from 14.7 to $16.8^{\circ} \mathrm{C}$, indicating the water body in a lower temperature environment. The conductivity in water directly correspond to the concentration of ions present in it. The vales of electrical conductivity (EC) range from 400 to $443 \mu \mathrm{s} / \mathrm{cm}$. The water samples from No. 1, No. 2, No. 3 lake are dominantly alkaline, with average ph values of $8.45,8.34$, and 8.36 respectively. In addition, the ph values of all samples are within the acceptable range according to the World Health Organization guidelines (WHO 1997) and China's national standard for drinking water. The TDS content from the 3 lakes grade from 185.61 to $221.41 \mathrm{mg} / 1$, showing the following the order: No. 1 (average content: $218.90 \mathrm{mg} / \mathrm{l}$ ) $>$ No. 2 (average content:194.35 mg/l)>No.3 (average content: $410.38 \mathrm{mg} / \mathrm{l})$. All samples from the area have TDS value below the desirable limit of $500 \mathrm{mg} / 1$ recommend by WHO (1997).

In general, $\mathrm{Ca}^{2+}$ and $\mathrm{Mg}^{2+}$ of samples are the two most abundant cation, followed by $\mathrm{Na}^{+} \cdot \mathrm{HCO}_{3}^{-}$ and $\mathrm{SO}_{4}^{2-}$ are the leading anion, followed by $\mathrm{Cl}^{-}$. The mean cation of all samples show the same decreasing trends: $\mathrm{Ca}^{2+}>\mathrm{Mg}^{2+}>\mathrm{Na}^{+}>\mathrm{K}^{+}$. However, the mean anion in samples show different trends: No.1 lake with the order: $\mathrm{SO}_{4}{ }^{2-}>\mathrm{HCO}_{3}>\mathrm{Cl}^{-}>\mathrm{F}^{-}$, No. 2 and No. 3 lakes with the order: $\mathrm{HCO}_{3}>\mathrm{SO}_{4}{ }^{2-}>\mathrm{Cl}^{-}>\mathrm{F}^{-}$. The ANOVA analysis was used to compare characteristics of water samples from 3 lakes. As can be seen in Fig. 2, the concentration of TDS, $\mathrm{Ca}^{2+}$ and $\mathrm{SO}_{4}^{2-}$ have the same decreasing trends: No. $1>$ No. $2>$ No. 3 . Comparatively, the concentration of $\mathrm{Na}^{+}$and $\mathrm{K}^{+}$follow the same decreasing trends: No. $1<$ No. $2<$ No. 3 . The concentration of $\mathrm{Mg}^{2+}$ and $\mathrm{HCO}_{3}^{-}$have the same decreasing trends: No. $1<$ No. $3<$ No. 2. The different trends in geochemical data of water samples may attributed to different hydrogeochemical process [17].

\section{Hydrochemical Type}

The Piper's trilinear diagram is a useful method to reveal the hydrogeochemical characteristics and evolution process of water samples [18]. The plot of the chemical data on Piper's trilinear diagram (Fig .3) shows that water samples around abandoned quarries area fall in regions mainly 1,4 and rarely in region 3 , indicating the dominance of alkaline earth $\left(\mathrm{Na}^{+}+\mathrm{K}^{+}\right)$exceeding alkalies and the strong acids $\left(\mathrm{SO}_{4}{ }^{2-}+\mathrm{Cl}^{-}\right)$slightly exceeding weak acids $\left(\mathrm{HCO}_{3}^{-}\right)$. The hydrochemical type of samples from No.1 lake is dominated by $\mathrm{SO}_{4} \mathrm{HCO}_{3}$ Ca.Mg (100\%). With the rise in $\mathrm{HCO}_{3}^{-}$content and decrease in $\mathrm{SO}_{4}^{2-}$, the hydrochemical type of samples from No. 2 and No. 3 lakes has been changed to $\mathrm{HCO}_{3}$. $\mathrm{SO}_{4}-\mathrm{Ca} \cdot \mathrm{Mg}(88.24 \%)$ and $\mathrm{SO}_{4} \mathrm{HCO}_{3}-\mathrm{Ca} \cdot \mathrm{Mg}(11.76 \%)$, 

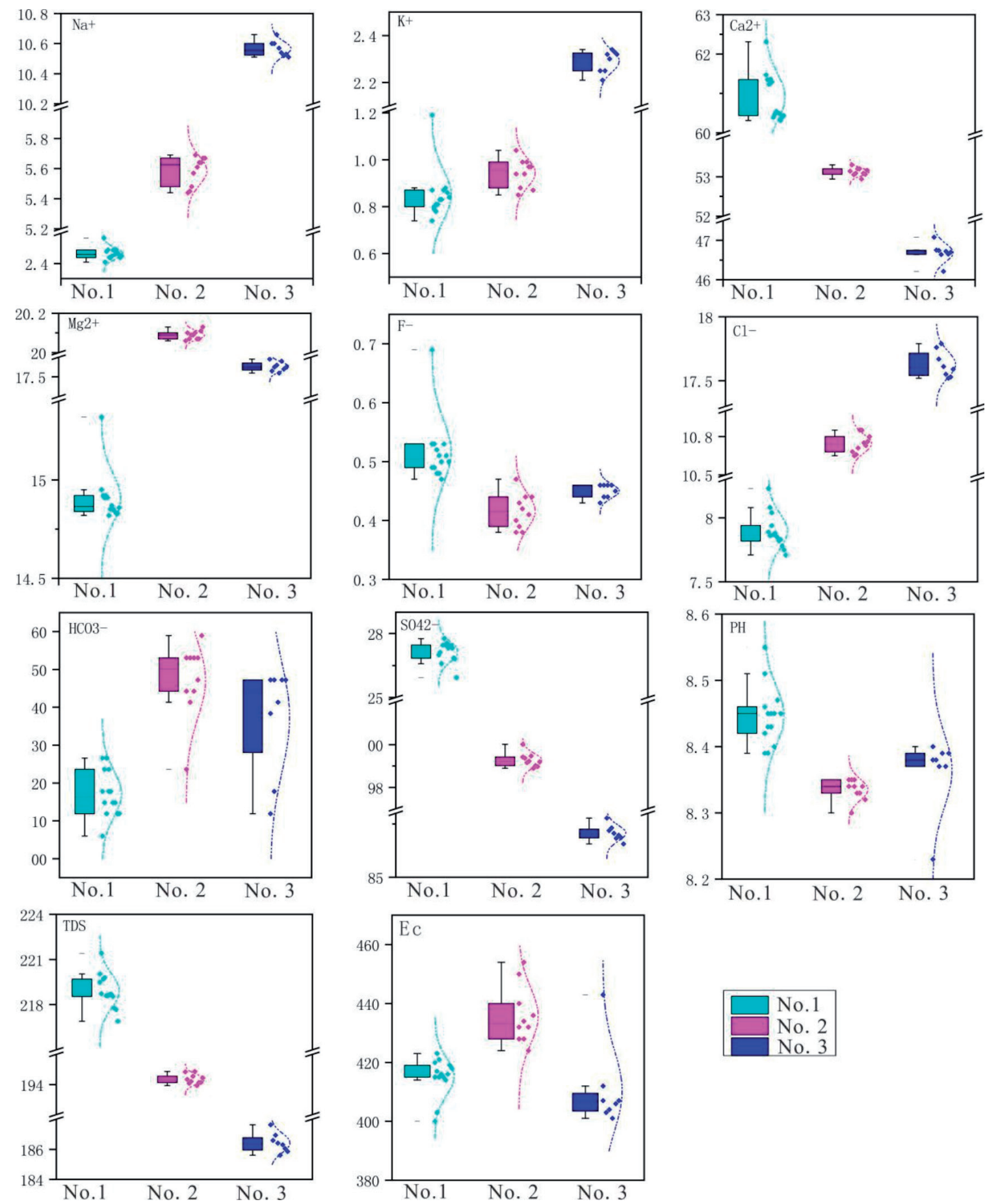

Fig. 2. Box plots of parameters of samples from 3 typical lakes.

resulting in the left and downward shifting of data point in the ternary anions diagram. For cations, all water samples are concentrated in region A, implying the calcium minerals dissolution play an important role during hydrogeochemical process. For anions, samples from No.1 lake fall in regions $F$, whereas samples from No. 2 and No. 3 fall in regions B and E, indicating the relation to sulfate and bicarbonate minerals dissolution, respectively. In general, the hydrochemical type of water samples from No. 2, No. 3 lakes are more complex and diverse than that of No.1 lake.

\section{Hydrogeochemical Process}

\section{Hydrogeochemical Behavior}

The interaction between surrounding rock and water play an important role during the hydrogeochemical process [19]. The ion ratio can be used to reveal valuable information such as chemical composition and source of water [20-21].

If halite is the only dissolved mineral, the mole ratio between $\mathrm{Na}^{+}$and $\mathrm{Cl}^{-}$in water should be 1:1. If the ratio 

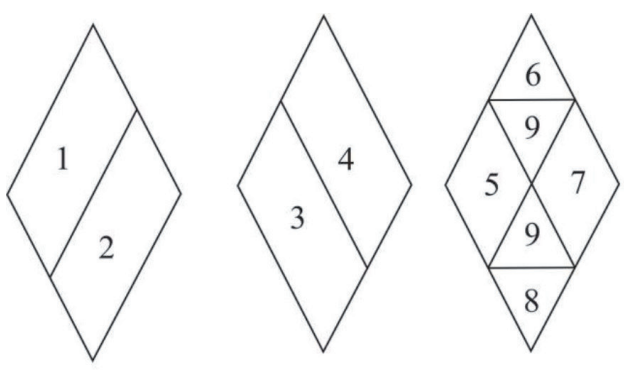

1 Alkaline earth exceeding alkalies

2 Alkalies exceeding alkaline earth

3 Weak acids exceeding strong acids

4 Strong acids exceeding weak acids

$5 \mathrm{HCO}_{3}-\mathrm{Ca} \cdot \mathrm{Mg}$

$6 \mathrm{SO}_{4} \cdot \mathrm{Cl}-\mathrm{Ca} \cdot \mathrm{Mg}$

$7 \mathrm{SO}_{4} \cdot \mathrm{Cl}-\mathrm{Na}$

$8 \mathrm{HCO}_{3}-\mathrm{Na}$

9 Mixed type

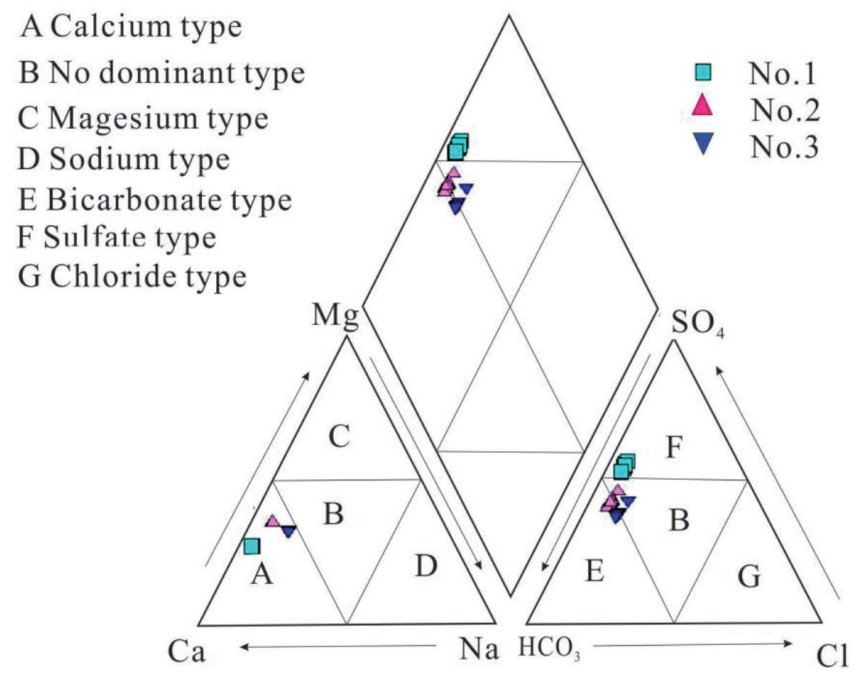

Fig. 3. Piper trigram of samples from 3 typical lakes.

exceeds 1 , it means the dissolution of silicate minerals and waste-water, whereas the ratio is less than 1 , it indicate the dissolution of carbonate minerals and/or ion exchange [22]. As shown in Fig. 4a), the date points of samples all appear below the $\mathrm{NaCl}$ dissolution line, which imply the existence of other source except halite. The points deviated from the 1:1 dissolution line can be explained by the water-rock interaction, such as the dissolution of carbonate minerals and/or ion exchange.

If the mole ratio between $\left(\mathrm{Ca}^{2+}+\mathrm{Mg}^{2+}\right)$ and $\left(\mathrm{HCO}_{3}\right.$ $+\mathrm{SO}_{4}^{2-}$ ) in groundwater equal to $1: 1$, it means $\mathrm{Ca}^{2+}$, $\mathrm{Mg}^{2+}$ are all derived from the dissolution of carbonate minerals (calcite, dolomite, and gypsum). The point fall below the 1:1 dissolution line, suggesting the effect of silicate minerals weathering. On the contrary, the point appear above the the 1:1 dissolution line, indicating the effect of carbonate [23]. As shown in Figure. 4.b, the date points of samples appear on the upper right part of the 1:1 dissolution line, indicating carbonate dissolution is the main source of $\mathrm{Ca}^{2+}, \mathrm{Mg}^{2+}$, $\mathrm{HCO}_{3}{ }^{-}$and $\mathrm{SO}_{4}{ }^{2-}$. Besides, $10 \%$ of the samples (No. 2 lake) and $25 \%$ of the samples (No.3 lake) are located below the 1:1 dissolution line, indicating the presence of the excess of $\left(\mathrm{Ca}^{2+}+\mathrm{Mg}^{2+}\right)$. The result show that the chemical composition in the lakes are mainly controlled by carbonate dissolution, whereas the No. 2 and No. 3 lake are partly controlled by both carbonate and silicate dissolution.

Ion exchange is an important process in controlling the chemical composition of water. In order to identify whether cation exchange occurs, CA-1 and CA-2 are can be used to verify. Two indices are calculated by following equations:

$$
C A-1=\left[C l^{-}-\left(N a^{+}+K^{+}\right)\right] / C l^{-}
$$

$\mathrm{CA}-2=\left[\mathrm{Cl}^{-}-\left(\mathrm{Na}^{+}+\mathrm{K}^{+}\right)\right] /\left[\mathrm{HCO}_{3}^{-}+\mathrm{SO}_{4}{ }^{2-}+\mathrm{CO}_{3}{ }^{2-}+\mathrm{NO}_{3}^{-}\right]$

Positive values of CA-1 and CA-2 suggest that $\mathrm{Na}^{+}$ and $\mathrm{K}^{+}$in water have been exchanged by $\mathrm{Ca}^{2+}$ and $\mathrm{Mg}^{2+}$ in the surrounding rock, whereas negative values indicate there is a reverse exchange. In addition, the larger the absolute values are, the stronger the ion exchange interaction is. Meanwhile, if the value is equal to 0 , it means there is no ion exchange interaction during the hydrochemical process [24].

Fig. 4c) is the plot of CA-1 versus CA-2 of samples in this study. The date points of samples from No. 1 and No. 2 lakes all appear on positive negative part, indicating $\mathrm{Na}^{+}$and $\mathrm{K}^{+}$in lake have been replaced by $\mathrm{Ca}^{2+}$ and $\mathrm{Mg}^{2+}$ in surrounding rock. However, date points of samples from No.3 lake locate on the negative part, implying $\mathrm{Ca}^{2+}$ and $\mathrm{Mg}^{2+}$ in No. 3 lake have been replaced by $\mathrm{Na}^{+}$and $\mathrm{K}^{+}$in surrounding rock. This observation suggest that with the decrease in the concentration of $\mathrm{Ca}^{2+}$ and $\mathrm{Mg}^{2+}$ in lake, accompanied with an increase in the the concentration of $\mathrm{Na}^{+}$and $\mathrm{K}^{+}$in No. 3 lake (Table 1). Moreover, samples from No.1 have higher 

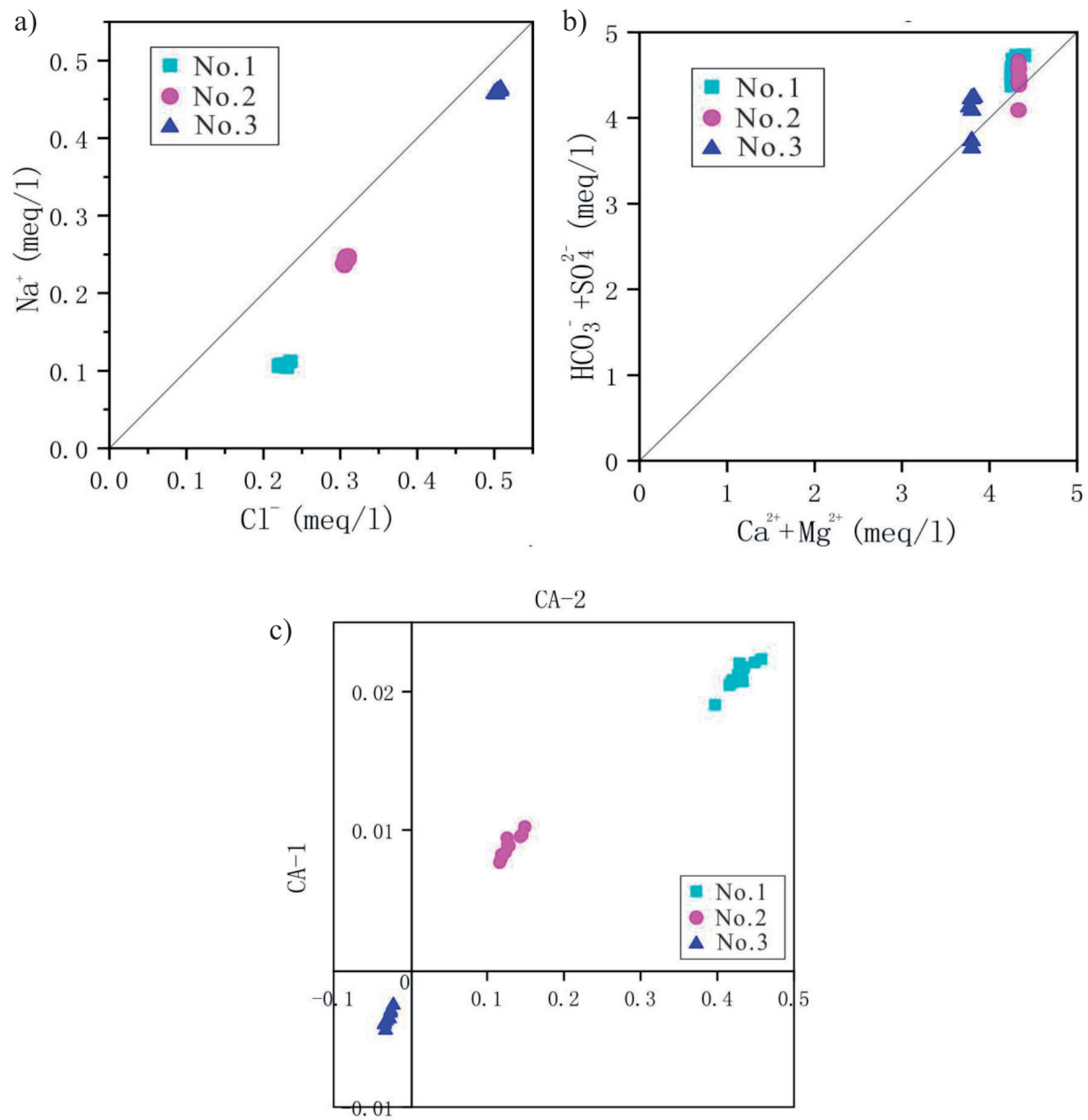

Fig. 4. Plots of a) $\mathrm{Cl}^{-}$versus $\mathrm{Na}^{+}$; b) $\left(\mathrm{HCO}_{3}{ }^{-}+\mathrm{SO}_{4}{ }^{2-}\right)$ versus $\left(\mathrm{Ca}^{2+}+\mathrm{Mg}^{2+}\right)$; c) the relationship between $\mathrm{CA}-1$ and $\mathrm{CA}-2$.

absolute values of CA-1 and CA-2 than those of No.2 and No. 3 lake in Fig. 4c), implying ion exchange interaction are more intense in No.1 lake.

\section{Formation Mechanisms of Chemical Component}

The relationships between $\mathrm{Na}^{+} /\left(\mathrm{Na}^{+}+\mathrm{K}^{+}\right)$for dominant cation and $\mathrm{Cl}^{-} /\left(\mathrm{Cl}^{-}+\mathrm{HCO}_{3}^{-}\right)$for dominant anion, and TDS are widely used to determined the mechanism of controlling chemical composition of water, including precipitation, rock dissolution and evaporation [25-26]. The Gibbs's diagram of water samples are plotted in Fig. 5. The data points all fall in the middle left of the diagram with medium TDS (obtained by field measurement) and lower ion ratio. The points located in rock dominance zone, but far away precipitation and evaporation dominance zone, suggesting that the major ion chemistry of the water samples is controlled by rock weathering dominance. The ion ratio perform horizontal drift with the rise in $\mathrm{Na}^{+} /\left(\mathrm{Na}^{+}+\mathrm{K}^{+}\right)$and $\mathrm{Cl}^{-} /\left(\mathrm{Cl}^{-}+\mathrm{HCO}_{3}^{-}\right)$from No. 1 lake to No. 3 lake, indicating different degree of rock weathering during hydrogeochemical process for water around abandoned quarries area.
The plot of $\mathrm{Mg}^{2+} / \mathrm{Na}^{+}$and $\mathrm{HCO}_{3}-/ \mathrm{Na}^{+}$versus $\mathrm{Ca}^{2+} / \mathrm{Na}^{+}$ are commonly way to assess whether evaporation, silicate weathering or/ and carbonate dissolution are involved in the water-rock interaction [27-28]. Fig. 6 is the plot of $\mathrm{Mg}^{2+} / \mathrm{Na}^{+}$and $\mathrm{HCO}_{3}{ }^{-} / \mathrm{Na}^{+}$versus $\mathrm{Ca}^{2+} / \mathrm{Na}^{+}$of all water samples in this study. The date points of samples fall between carbonate dominance zone and the silicate dominance zone, but far away the evaporation dominance, indicating the silicate weathering and carbonate dissolution are the main functions during hydrogeochemical process. As shown in Fig. 6, compared with the samples from No. 3 lake, the data points of samples from No.1 lake are closer to the carbonate dominance zone, suggesting water in No.1 lake possess more dissolved carbonate minerals, whereas water in No. 3 lake possess more dissolved silicate minerals and No. 2 lake are in between.

\section{Recharging Analysis}

Hydrogen and oxygen isotopes are the intrinsic components, which generally do not change with water rock interaction. Hence, the $\delta \mathrm{D}$ and $\delta^{18} \mathrm{O}$ are widely used as an ideal indicator to trace water recharge within 
Table 1. Geochemical data of samples collected in this study.

\begin{tabular}{|c|c|c|c|c|c|c|c|c|c|c|c|c|}
\hline \multirow{2}{*}{ Site } & \multirow{2}{*}{ Index } & $\mathrm{Na}^{+}$ & $\mathrm{K}^{+}$ & $\mathrm{Mg}^{2+}$ & $\mathrm{Ca}^{2+}$ & $\mathrm{F}^{-}$ & $\mathrm{Cl}^{-}$ & $\mathrm{SO}_{4}^{2-}$ & $\mathrm{HCO}_{3}-$ & TDS & \multirow{2}{*}{$\begin{array}{c}\mathrm{EC} \\
\mu \mathrm{s} / \mathrm{cm}\end{array}$} & \multirow{2}{*}{$\frac{\mathrm{PH}}{1}$} \\
\hline & & \multicolumn{9}{|c|}{$\mathrm{mg} / \mathrm{l}$} & & \\
\hline \multirow{4}{*}{$\begin{array}{c}\text { No.1 } \\
\mathrm{N}=14\end{array}$} & Min & 2.41 & 0.74 & 14.82 & 60.31 & 0.47 & 7.71 & 125.93 & 105.98 & 216.89 & 400.00 & 8.39 \\
\hline & Max & 2.57 & 1.19 & 15.32 & 62.31 & 0.69 & 8.23 & 127.76 & 126.59 & 221.41 & 423.00 & 8.55 \\
\hline & Mean & 2.47 & 0.85 & 14.91 & 60.90 & 0.52 & 7.90 & 127.15 & 117.13 & 218.90 & 415.14 & 8.45 \\
\hline & CV (\%) & 1.53 & 12.41 & 0.85 & 0.99 & 10.40 & 1.76 & 0.38 & 5.23 & 0.52 & 1.53 & 0.52 \\
\hline \multirow{4}{*}{$\begin{array}{c}\text { No. } 2 \\
\mathrm{~N}=10\end{array}$} & Min & 5.44 & 0.85 & 20.06 & 52.94 & 0.38 & 10.65 & 98.9 & 123.64 & 193.92 & 424 & 8.3 \\
\hline & Max & 5.69 & 1.04 & 20.13 & 53.3 & 0.47 & 10.85 & 100.02 & 158.97 & 194.86 & 454 & 8.35 \\
\hline & Mean & 5.59 & 0.94 & 20.09 & 53.12 & 0.42 & 10.74 & 99.28 & 147.19 & 194.35 & 435.80 & 8.34 \\
\hline & CV (\%) & 1.72 & 6.44 & 0.11 & 0.19 & 7.09 & 0.67 & 0.33 & 6.73 & 0.16 & 2.22 & 0.19 \\
\hline \multirow{4}{*}{$\begin{array}{c}\text { No.3 } \\
\mathrm{N}=7\end{array}$} & Min & 10.51 & 2.21 & 17.52 & 46.21 & 0.43 & 17.52 & 86.56 & 111.87 & 185.61 & 401 & 8.23 \\
\hline & Max & 10.66 & 2.34 & 17.59 & 47.08 & 0.46 & 17.79 & 87.78 & 147.2 & 187.63 & 443 & 8.4 \\
\hline & Mean & 10.57 & 2.29 & 17.55 & 46.69 & 0.45 & 17.63 & 87.07 & 137.26 & 186.42 & 410.38 & 8.36 \\
\hline & CV (\%) & 0.49 & 2.06 & 0.14 & 0.51 & 2.66 & 0.59 & 0.42 & 10.44 & 0.34 & 3.31 & 0.66 \\
\hline
\end{tabular}

water circulation system [29-30]. By studying the natural meteoric waters from many parts of the word, there is a linear relationship between stable isotopes of $\delta \mathrm{D}$ and $\delta^{18} \mathrm{O}$ defined by Craig in 1961, which is expressed as $\delta \mathrm{D}=8 \delta^{18} \mathrm{O}+10$ and referred to as the Global Meteoric Water Line (GMWL) [31]. Usually, the point of a water sample falls near the GMWL, which means the recharge source is atmospheric precipitation. The deviation of a water sample below the GMWL imply the existence of evaporation after precipitation recharging. Besides, the further a water sample deviates from the GMWL, the stronger evaporation is. In addition, D-excess $\left(\mathrm{d}=\delta \mathrm{D}-8 \delta^{18} \mathrm{O}\right)$ can reflect the degree of imbalance of evaporation and condensation process of regional

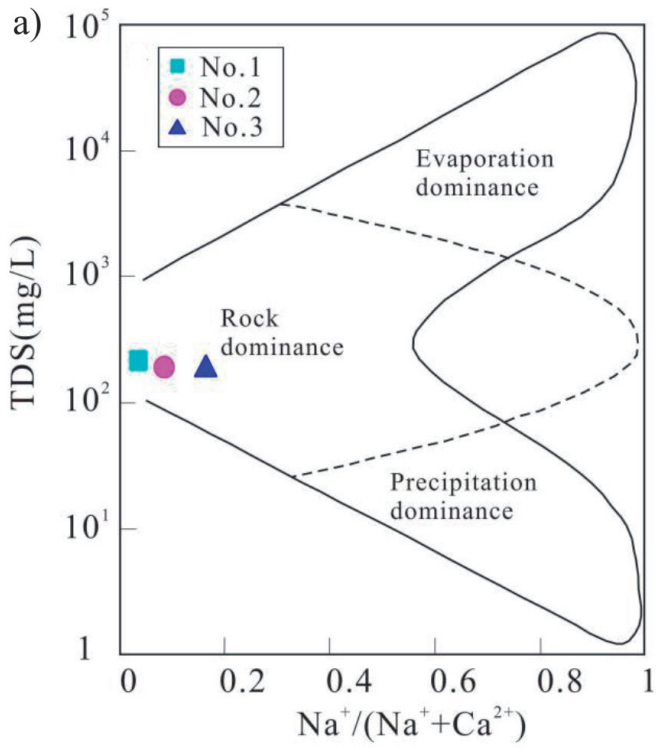

atmospheric precipitation. The smaller the D-excess value is, the stronger the imbalance of evaporation and condensation is, and the larger the D-excess value is, the weaker the imbalance [32]. The values of $\delta \mathrm{D}, \delta^{18} \mathrm{O}$, and D-excess in the study area are listed in Table 2.

As can be seen in Table 2, all samples of three lakes show negative $\delta \mathrm{D}$ and $\delta^{18} \mathrm{O}$ value. The $\delta \mathrm{D}$ value of No.1 lake samples range from -38.68 to -31.67 , with an average of -36.52 , and their $\delta^{18} \mathrm{O}$ values range from -5.15 to -3.91 , with an average of -4.29 . In No.2 lake, the $\delta \mathrm{D}$ value range from -36.27 to -33.18 , with an average of -35.44 , and the $\delta^{18} \mathrm{O}$ values range from -4.32 to -3.92 , with an average of -4.10 . For samples from No. 3 lake, the $\delta \mathrm{D}$ value range from -41.46 to -38.55 , with an

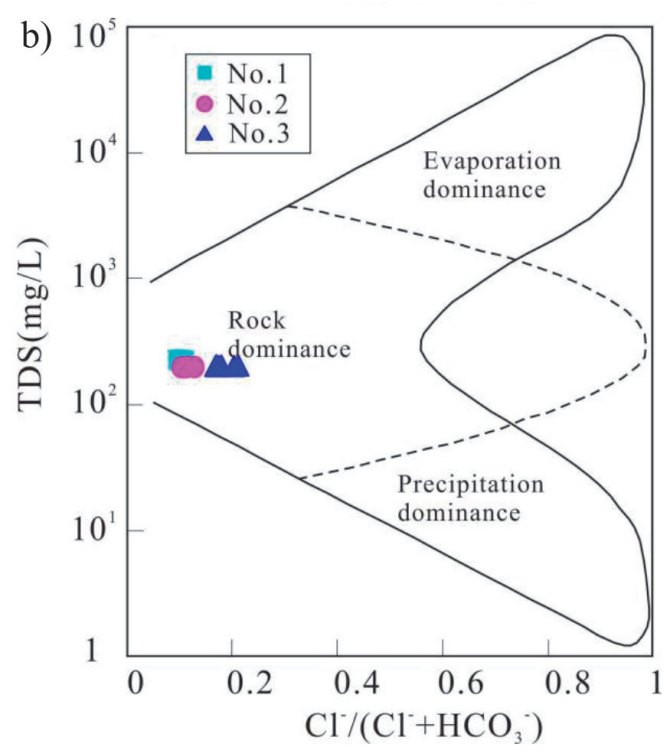

Fig. 5. Gibb's diagram of samples. a) cationic; b) anionic. 

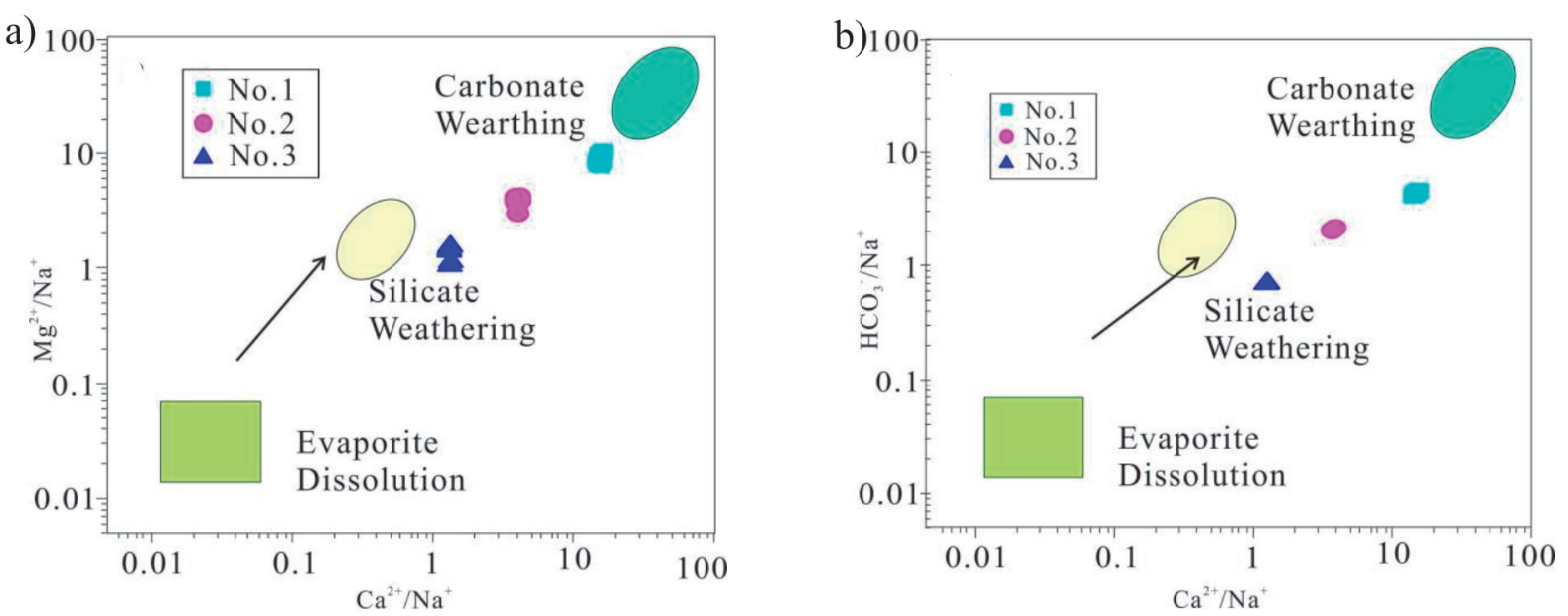

Fig. 6. The relationship between $\mathrm{HCO}_{3}^{-} / \mathrm{Na}^{+}$and $\mathrm{Ca}^{2+} / \mathrm{Na}^{+}$a) and between $\mathrm{Mg}^{2+} / \mathrm{Na}^{+}$and $\mathrm{Ca}^{2+} / \mathrm{Na}^{+}$b).

Table 2. characteristic statistics of oxygen and hydrogen isotope.

\begin{tabular}{|c|c|c|c|c|c|c|c|c|c|c|}
\hline \multirow{2}{*}{ Parameters } & \multirow{2}{*}{ Unit } & \multicolumn{3}{|c|}{ No.1 lake } & \multicolumn{3}{c|}{ No.2 lake } & \multicolumn{3}{c|}{ No.3 lake } \\
\cline { 3 - 13 } & & Min & Max & Mean & Min & Max & Mean & Min & Max & Mean \\
\hline$\delta \mathrm{D}$ & $\%$ & -38.68 & -31.67 & -36.52 & -36.27 & -33.18 & -35.435 & -41.46 & -38.55 & -40.15 \\
\hline$\delta^{18} \mathrm{O}$ & $\%$ & -5.15 & -3.91 & -4.29 & -4.32 & -3.92 & -4.103 & -4.59 & -3.96 & -4.31 \\
\hline $\mathrm{D}$-excess & $\%$ & -6.48 & 9.51 & -2.18 & -4.89 & 0.95 & -2.61 & -9.8 & -3.04 & -5.65 \\
\hline
\end{tabular}

average of -40.15 , and the $\delta^{18} \mathrm{O}$ values range from -4.59 to -3.96 , with an average of -4.31 . The D-excess values of all samples are significantly lower than that of Global Meteoric Water Line (10\%), implying the influence of evaporation lead to enrichment of hydrogen and oxygen isotopes during the formation of lake. Besides,

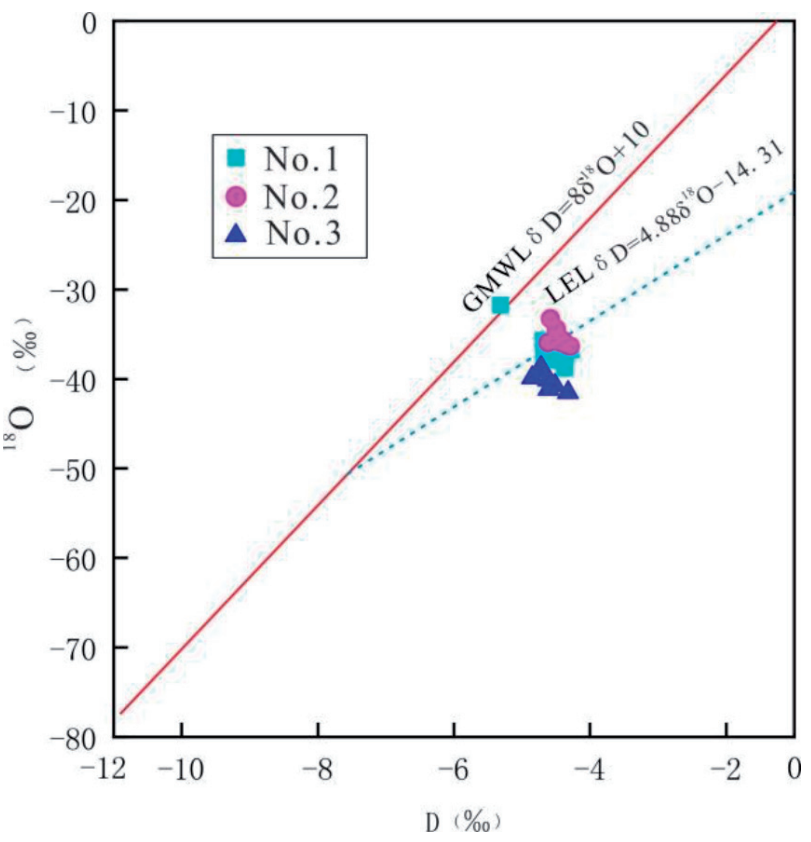

Fig. 7. The plot of $\delta^{18} \mathrm{O}$ versus $\delta \mathrm{d}$. the samples from No.3 lake has smaller values of D-excess than that of samples from No. 1 lake and No. 2 lake in Table 2, indicating imbalance of evaporation are more stronger in No. 3 lake.

The values of $\delta \mathrm{D}$ and $\delta^{18} \mathrm{O}$ described in the $\delta \mathrm{D}-\delta^{18} \mathrm{O}$ coordinate system composed of the Global Meteoric Water line (GMWL), the regional Local Evaporation line (LEL) [33-34], and water samples in this study, as shown in Fig. 7. The data points of water samples all appear below the GMWL and near the LEL, suggesting the recharge of water samples from abandoned quarries area is mainly derived from atmospheric precipitation. Compared with the points of samples from No. 1 and No. 2 lake, the date point of samples from No. 3 lake have lower values of $\delta^{18} \mathrm{O}$, showing vertical drift with the decrease of $\delta^{18} \mathrm{O}$. The result indicate that evaporation are more tense in No. 3 lake, which is consistent with the conclusion of D-excess.

\section{Water Quality Assessment \\ Water Quality for Drinking}

The prescribed limits of the World Health Organization guidelines (WHO 1997) are used to assess the suitability for drinking. The major geochemical parameters are listed in Table 3. As can be seen in Table 3, the concentration of all major ions are within the maximum desirable limit prescribed by WHO 
Table 3. Geochemical parameters of the study area in comparison to WHO (1997).

\begin{tabular}{|c|c|c|c|c|c|c|}
\hline \multirow{2}{*}{ Major ions } & \multirow{2}{*}{ Unit } & \multicolumn{3}{|c|}{ Samples from 3 lakes } & \multicolumn{2}{c|}{ WHO(1997) } \\
\cline { 3 - 7 } & & Min. & Max. & Mean & Desirable & Permissble \\
\hline $\mathrm{Na}^{+}$ & $\mathrm{mg} / \mathrm{l}$ & 2.41 & 10.66 & 5.47 & 50.00 & 200 \\
\hline $\mathrm{K}^{+}$ & $\mathrm{mg} / 1$ & 0.74 & 2.34 & 1.24 & 100.00 & 200 \\
\hline $\mathrm{Mg}^{2+}$ & $\mathrm{mg} / 1$ & 14.82 & 20.13 & 17.19 & 30.00 & 150 \\
\hline $\mathrm{Ca}^{2+}$ & $\mathrm{mg} / 1$ & 46.21 & 62.31 & 54.91 & 75.00 & 200 \\
\hline $\mathrm{F}^{-}$ & $\mathrm{mg} / 1$ & 0.38 & 0.69 & 0.47 & $0.6-0.9$ & 1.5 \\
\hline $\mathrm{Cl}^{-}$ & $\mathrm{mg} / 1$ & 7.71 & 17.79 & 11.22 & 250.00 & 600 \\
\hline $\mathrm{SO}_{4}^{2-}$ & $\mathrm{mg} / 1$ & 86.56 & 127.76 & 108.42 & 200.00 & 600 \\
\hline $\mathrm{HCO}_{3}^{-}$ & $\mathrm{mg} / 1$ & 105.98 & 158.97 & 131.56 & 200.00 & 600 \\
\hline $\mathrm{PH}^{-2}$ & $/$ & 8.23 & 8.55 & 8.39 & $7.0-8.5$ & $6.5-9.2$ \\
\hline $\mathrm{TDS}$ & $\mathrm{mg} / 1$ & 185.61 & 221.41 & 203.11 & 500.00 & 1500 \\
\hline $\mathrm{EC}$ & $\mu \mathrm{cm}$ & 400.00 & 454.00 & 420.41 & 750.00 & 1500 \\
\hline
\end{tabular}

standard (1997), confirming their suitability for drinking purpose. Good water environment around abandoned quarries area is related to strict laws and environmental protection measures implemented by local government. Meanwhile, the study area is far away from the urban and industrial pollution sources, possessing high ecological environment purification capacity. The observation indicate water around abandoned quarries area is suitable for drinking.

\section{Irrigation Use}

Surface water accounts for a large proportion in agricultural irrigation, thus evaluation for irrigation use is of great significance to agricultural production [35]. The electrical conductivity (EC) and $\mathrm{Na}^{+}$play a fundamental role in water quality for irrigation use [36]. A high salinity in water lead to poor permeability and hence affect migration of water and the absorption of nutrients from soil [37]. Excess amount of dissolved ion influence the physical and chemical properties of soils. In the present study, the single parameters such as the Sodium absorption ratio (SAR), Percent sodium $(\% \mathrm{Na})$, Residual sodium carbonate (RSC), Residual sodium bicarbonate (RSBC), Mg ratio (MR), Kelley's ratio (KR), and Permeability index (PI) have been estimated its suitability for irrigation use. In addition, the US Salinity Laboratory diagram (USSL) and Wilcox diagram has been also used for irrigation purpose.

\section{Sodium Absorption Ratio (SAR)}

SAR is an important parameter that can reflect the degree of sodium exchange with calcium and magnesium in soil, and also reflect the influence on crops, expressing as: $\mathrm{SAR}=\mathrm{Na}^{+} / \sqrt{ }\left[\left(\mathrm{Ca}^{2+}+\mathrm{Mg}^{2+}\right) / 2\right]$.
If the SAR value of water is less than 10 then the water belongs to excellent quality for irrigation, it is good quality if the value grades between $10-18$, and if it is between $18-26$ it is fair, and above 26 is referred to unsuitable for irrigation [38]. In this study, the calculated SAR values range from 0.39 to $1.88 \mathrm{meq}^{-1 / 2}$, suggesting excellent quality for irrigation use. Meanwhile, the date points of samples all falling in C2S1 category of USSL diagram [39] indicate the water medium salinity-low alkalinity type and thus can be utilized for irrigation with very little danger of changeable salinity (Fig. 8).

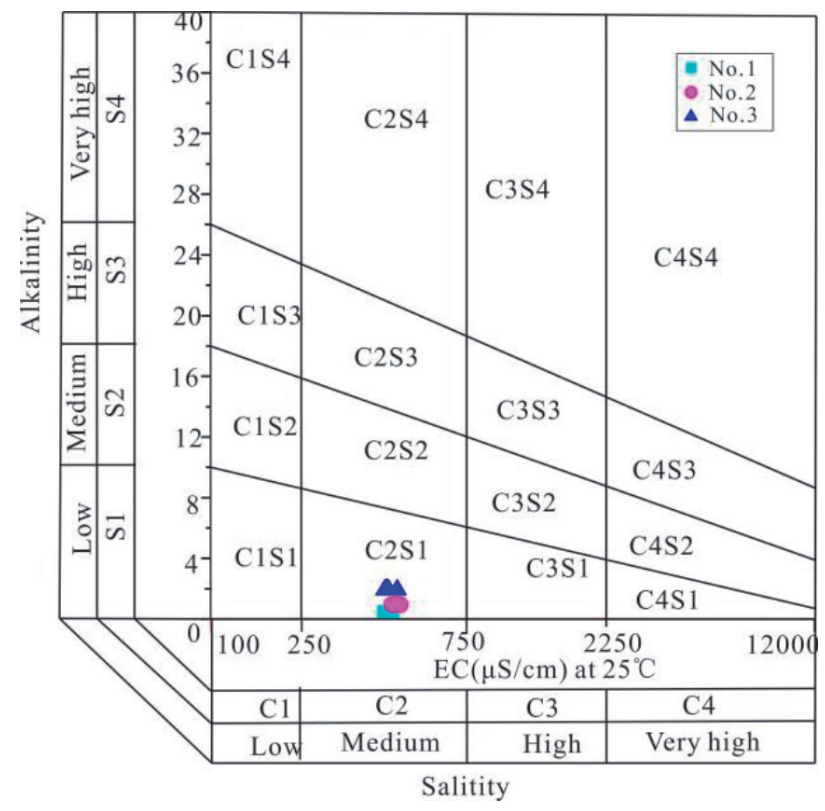

Fig. 8. USSL diagram of samples. 


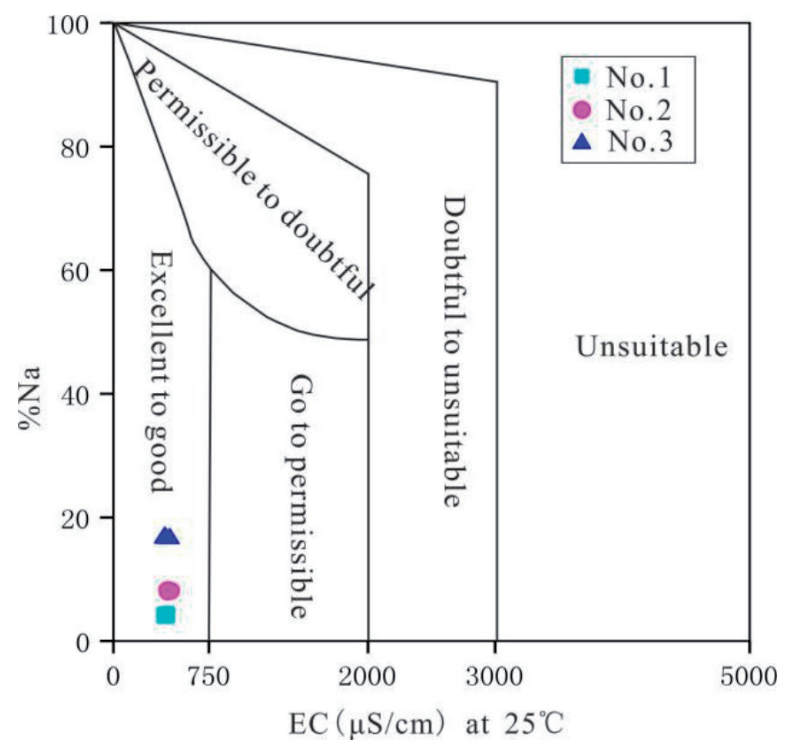

Fig. 9. Wilcox diagram of samples.

\section{Percent Sodium $(\% \mathrm{Na})$}

The $\% \mathrm{Na}$ is also a useful way to assess the suitability for irrigation, which is calculated by the following formula as: $\% \mathrm{Na}=\left(\mathrm{Na}^{+} \times 100\right) /\left(\mathrm{Ca}^{2+}+\right.$ $\mathrm{Mg}^{2+}+\mathrm{Na}^{+}+\mathrm{K}^{+}$). High $\% \mathrm{Na}$ in irrigation water will reduce permeability of soil and causes soil to harden. The $\% \mathrm{Na}<60$ means safe water while it is unsafe if $>60$ [40]. The $\% \mathrm{Na}$ in this study area ranges from 4.03 to 16.76. According to the above criteria, the water is safe for irrigation use. In Wilcox's diagram [41], the data points of all samples fall into the Excellent to good filed, indicating the water around abandoned quarries area is excellent for irrigation (Fig. 9).

\section{Residual Sodium Carbonate (RSC)}

A high RSC value in water lead to a rise in the adsorption of sodium soil. RSC for water samples of the study area was calculated by the following formula as: $\mathrm{RSC}=\left(\mathrm{CO}_{3}^{2}+\mathrm{HCO}_{3}^{-}\right)-\left(\mathrm{Ca}^{2+}+\mathrm{Mg}^{2+}\right)$. Water with RSC value $<1.25 \mathrm{meq} / 1$ is considered as it is suitable for the irrigation purpose, $1.25-2.5 \mathrm{meq} / 1$ is marginal suitable, between $2.5-5 \mathrm{meq} / 1$ is unsuitable and $>5 \mathrm{meq} / 1$ is harmful to the growth of plants. In the study, all the samples have RSC $<1.25 \mathrm{meq} / 1$ (maximum $1.38 \mathrm{meq} / 1$ ), hence suitable for irrigation.

\section{Residual Sodium Bicarbonate (RSBC)}

The RSBC is often used to distinguish the difference of bicarbonate to calcium and calculated as: $\mathrm{RSBC}=\mathrm{HCO}_{3}^{-}-\mathrm{Ca}^{2+}$. The value of $\mathrm{RSBC}<5$ is satisfactory, between $5-10$ is marginal and $>10$ is unsatisfactory [42]. The maximum RSBC value of water in the study area is 0.08 , suggesting its satisfactory for irrigation.

\section{Mg Ratio (MR)}

Excess concentration of magnesium can damage the quality of soil and reduce yield of crops. Magnesium ratio is classified as: $\mathrm{MR}=\left(\mathrm{Mg}^{2+} \times 100\right) /\left(\mathrm{Ca}^{2+}+\mathrm{Mg}^{2+}\right)$. The $\mathrm{MR}<50$ represent suitable for irrigation while it is unsuitable if $M R>50$ [38]. The calculated $M R$ values range from 28.83 to 38.73 , implying water samples is good for irrigation.

\section{Kelley's Ratio (KR)}

The relationships between $\mathrm{Na}^{+}$and $\left(\mathrm{Ca}^{2+}+\mathrm{Mg}^{2+}\right)$ is express as Kelley's ratio and calculated as $\mathrm{KR}=\mathrm{Na}^{+} /\left(\mathrm{Ca}^{2+}+\mathrm{Mg}^{2+}\right)$. The water having $\mathrm{KR}<1$ is categorized as good quality for irrigation whereas $\mathrm{KR}<1$ is considered to be unsuitable for irrigation and lead to alkali hazard [43]. The maximum KR value of water in the study area is 0.12 , indicating its suitable for irrigation.

\section{Permeability Index (PI)}

Soil permeability is the main factor controlled by the long-term use of irrigation water and related to the content of sodium, bicarbonate, calcium and magnesium, etc, which is determined by: $\mathrm{PI}=\left[\left(\mathrm{Na}^{+}+\sqrt{ } \mathrm{HCO}_{3}^{-}\right) /\left(\mathrm{Ca}^{2+} \mathrm{Mg}^{2+}+\mathrm{Na}^{+}\right)\right] \times 100$. It is divided into class I, class II and class III depending on PI values [44]. The calculated result of PI values ranging from 33 to 47 fall in class I, which indicate good quality for irrigation.

\section{Conclusions}

In this study, water from 3 lakes around abandoned quarries area were analyzed and water quality for were assessed for drinking and irrigation. Main conclusions obtained from this research are listed as follows:

(1) The water around the Fuli abandoned quarries was dominantly alkaline in nature. The mean cation of all samples showed the same decreasing trends: $\mathrm{Ca}^{2+}>\mathrm{Mg}^{2+}>\mathrm{Na}^{+}>\mathrm{K}^{+}$. However, the mean anion show different trends, and No. 1 lake with order: $\mathrm{SO}_{4}{ }^{2-}>\mathrm{HCO}_{3}$ $>\mathrm{Cl}^{-}>\mathrm{F}^{-}$, No. 2 and No. 3 lakes with order: $\mathrm{HCO}_{3}>\mathrm{SO}_{4}^{2-}$ $>\mathrm{Cl}^{-}>\mathrm{F}^{-}$. The hydrochemical type of water samples from No. 2, No. 3 lake were more complex and diverse than that of No. 1 lake. The hydrochemical type of No.1 lake was dominated by $\mathrm{SO}_{4} \mathrm{HCO}_{3}-\mathrm{Ca} \cdot \mathrm{Mg}(100 \%)$, whereas the hydrochemical type of No.2 and No.3 lake has been changed to $\mathrm{HCO}_{3} \mathrm{SO}_{4-} \mathrm{Ca} \cdot \mathrm{Mg}(88.24 \%)$ and $\mathrm{SO}_{4} \mathrm{HCO}_{3}-$ Ca.Mg (11.76\%).

(2) The chemical composition in the No.1 lake were mainly controlled by carbonate dissolution and ion-exchange, whereas the No.2 and No.3 lake were governed by both ion-exchange and dissolution of carbonate and silicate minerals. In addition, the rock 
weathering dominance was the most important factor that control the chemical composition.

(3) Stable isotope analysis showed that the recharging of study area was mainly derived from atmospheric precipitation. The deviation from the GMWL and low value of D-excess indicate that imbalance of evaporation were stronger in No. 3 lake than in No. 1 and No. 2 lake. The result of water quality assessment indicated that water around abandoned quarries area could be used for drinking and suitable for irrigation use without any hazards.

\section{Acknowledgments}

This research was funded by the Key Natural Science Research Projects of Suzhou University (2020yzd03, 2020yzd07, 2019yzd01), National Natural Science Foundation of China (41773100) and Funding projects for research activities of academic and technological leaders of Anhui Province (2020D239).

\section{Conflict of Interest}

The authors declare no conflict of interest.

\section{References}

1. GUO J.L., YU Y.L., WU G.J., MA M.Y. Characteristics of surface water quality and stable isotopes in Bamen Bay watershed, Hainan Province, China. PLoS ONE, 16 (1), 1, 2021.

2. HUANG Z.F., ZHENG S.S., LIU Y., ZHAO X.R., QIAO X.C., LIU C.Y., ZHENG B.H., YIN D.Q. Distribution, toxicity load, and risk assessment of dissolved metal in surface and overlying water at the Xiangjiang River in southern China. Scientific Reports, 11 (1), 1, 2021.

3. KANT N., SINGH P.K., KUMAR B. Hydrogeochemical Characterization and Groundwater Quality of Jamshedpur Urban Agglomeration in Precambrian Terrain, Eastern India. Journal of the Geological Society of India, 92 (1), 67, 2018.

4. KHAN A., KHAN A., KHAN F.A., SHAH L.A., RAUF A.U., BADRASHI Y.I., KHAN W., KHAN J. Assessment of the Impacts of Terrestrial Determinants on Surface Water Quality at Multiple Spatial Scales. Polish Journal of Environmental Studies, 30 (3), 2137, 2021.

5. WU P., TANG C.Y., LIU C.Q., ZHU L.J., PEI T. Q., FENG L.J. Geochemical distribution and removal of $\mathrm{As}, \mathrm{Fe}, \mathrm{Mn}$ and $\mathrm{Al}$ in a surface water system affected by acid mine drainage at a coalfield in Southwestern China. Environmental Geology, 57 (7), 1457, 2009.

6. MARKAD A.T., LANDGE A.T., NAYAK B.B., INAMDAR A.B., MISHRA A.K. A multivariate statistical approach for the evaluation of spatial and temporal dynamics of surface water quality from the small reservoir located in the drought-prone area of South-West India: a case study of Tiru reservoir (India). Environmental Science and Pollution Research International, 28 (24), 31013, 2021.
7. ZHANG B., SONG X.F., ZHANG Y.H., HAN D.M., TANG C.Y., YU Y.L., MA Y. Hydrochemical characteristics and water quality assessment of surface water and groundwater in Songnen plain, Northeast China. Water Research, 46 (8), 2737, 2012.

8. ASARE-DONKOR N.K., OFOSU J.O., ADIMADO A.A. Hydrochemical characteristics of surface water and ecological risk assessment of sediments from settlements within the Birim River basin in Ghana. Environmental Systems Research, 7 (1), 9, 2018.

9. ASARE-DONKOR N.K., ADIMADO A.A. Influence of mining related activities on levels of mercury in water, sediment and fish from the Ankobra and Tano River basins in South Western Ghana. Environmental Systems Research, 5 (1), 1, 2016.

10. ZHAO D., WANG G.C., LIAO F., YANG N., JIANG W.J., GUO L., LIU C.L., SHI Z.M. Groundwater-surface water interactions derived by hydrochemical and isotopic ( 222 $\mathrm{Rn}$, deuterium, oxygen-18) tracers in the Nomhon area, Qaidam Basin, NW China. Journal of Hydrology, 565, 650, 2018.

11. BORZI G., TANJAL C., SANTUCCI L., CAROL E. Geochemical mechanisms controlling the isotopic and chemical composition of groundwater and surface water in a sector of the Pampean plain (Argentina). Science of the Total Environment, 683 (SEP.15), 455, 2019.

12. GE J., CHEN J.S., GE L., WANG T., WANG C., CHEN Y.F. Isotopic and hydrochemical evidence of groundwater recharge in the Hopq Desert, NW China. Journal of Radioanalytical \& Nuclear Chemistry, 310 (2), 761, 2016.

13. WORLD HEALTH ORGANIZATION. Guideline for drinking water quality, Geneva, 1997.

14. AYERS R.S., WESTCOT D.W. Water quality for agriculture. Irrigation \& Drainage Paper, 29 (4490), 628, 1976.

15. SHAHAB A., QI S.H., ZAHEER M., RASHID A., ASHRAF U. Hydrochemical characteristics and water quality assessment for drinking and agricultural purposes in District Jacobabad, Lower Indus Plain, Pakistan. International Journal of Agricultural \& Biological Engineering, 11 (2), 115, 2018.

16. FANG T., XIE G.A., WANG B., ZHANG Q.L., XIE S.Y. Structural characteristics and formation mechanism of Huaibei coalfield. Coal Geology and Exploration, 45 (03), 1-6+12, 2011.

17. HAO C.M., ZHANG W., GUI H.R. Hydrogeochemistry characteristic contrasts between low- and high-antimony in shallow drinkable groundwater at the largest antimony mine in hunan province, China. Applied Geochemistry, 117 (24), 104584, 2020.

18. DARWESH N., ALLAM M., QINGYAN M., HELFDHALLAH A.A., KHARRIM K.E., MALIKI A.A.A., BELGHYTI D. Using Piper trilinear diagrams and principal component analysis to determine variation in hydrochemical faces and understand the evolution of groundwater in Sidi Slimane Region, Morocco. Egyptian Journal of Aquatic Biology \& Fisheries, 23 (5), 17, 2019.

19. SUN L.H., GUI H.R. Water rock interaction in deep groundwater aquifers of coal mining area: Qualitative and quantitative approaches based on hydrochemistry. Indian journal of geo-marine sciences, 46 (5), 877, 2017.

20. GUO Y., WEI J.C., GUI H.R., ZHANG Z., HU M.C. Evaluation of changes in groundwater quality caused by a water inrush event in Taoyuan coal mine, China. Environmental Earth Sciences, 79 (24), 2020. 
21. SÁNCHEZ-ESPA J., ERCILLA M.D., CERDÁN F.P., YUSTA I., BOYCE A. Hydrological investigation of a multi-stratified pit lake using radioactive and stable isotopes combined with hydrometric monitoring. Journal of Hydrology, 511, 494, 2014.

22. CHEN L.W., XU D.Q., YIN X.X., XIE W.P., ZENG W. Analysis on hydrochemistry and its control factors in the concealed coal mining area in North China: A case study of dominant inrush aquifers in Suxian mining area. Journal of China coal society, 42 (04), 996, 2017.

23. CHEN K., SUN L.H. Analysis of chemical composition and control factors of groundwater in Renlou coal mine. Coal science and technology, 47 (10), 240, 2019.

24. TAY C.K., KORTATSI B.K., HAYFORD E., HODGSON I.O. Origin of major dissolved ions in groundwater within the Lower Pra Basin using groundwater geochemistry, source-rock deduction and stable isotopes of ${ }^{2} \mathrm{H}$ and ${ }^{18} \mathrm{O}$. Environmental Earth Sciences, 71, 5079, 2014.

25. GIBBS R.J. Mechanisms controlling world water chemistry. Science (New York), 170, 1088-1090, USA, 1970.

26. OOSAWA Y., KASAI M. Gibbs-Donnan ratio and channel conductance of Tetrahymena cilia in mixed solution of $\mathrm{K}^{+}$ and $\mathrm{Ca}^{2+}$. Biophysical journal, 54 (3), 407, 1988.

27. MAGESH N.S., BOTSA S., DESSAI S., MESTRY M., TIWARI A. Hydrogeochemistry of the deglaciated lacustrine systems in Antarctica: Potential impact of marine aerosols and rock-water interactions. Science of the Total Environment, 706, 135822, 2020.

28. PAZAND K. Evaporites, Geochemical and statistical evaluation of spring water in Sarduiyeh Basin, SE Iran. Carbonates and Evaporites, 35 (1-4), 40, 2020.

29. MAHLANGU S., LORENTZ S., DIAMOND R., DIPPENAAR M. Surface water-groundwater interaction using tritium and stable water isotopes: A case study of Middelburg, South Africa. Journal of African Earth Sciences, 170, 103886, 2020.

30. FADHULLAH W., YACCOB S., SYAKIR M.I., MUHAMMAD S.A., YUE F.J., LI S.L. Nitrate sources and processes in the surface water of a tropical reservoir by stable isotopes and mixing model. Science of the Total Environment, 700, 134517, 2019.

31. CRAIG H. Isotopic Variations in Meteoric Waters. Science (New York), 133, 1702, 1961
32. JIANG Y.Q., GUI H.R., YU H., WANG M.C., FANG H.X., WANG C.L., CHEN C. ZHANG Y.R., HUANG Y.H. Hydrochemical Characteristics and Water Quality Evaluation of Rivers in Different Regions of Cities: A Case Study of Suzhou City in Northern Anhui Province, China. Water, 12 (4), 950, 2020.

33. GUO H.W., ZHU G.F., HE Y.Q., ZHOU J.J., PAN H.X., MA X.G., ZHANG Y., HUANG M.H., XIANG J. Dynamic Characteristics and Influencing Factors of Precipitation $\delta^{18} \mathrm{O}$, China. Theoretical \& Applied Climatology $138(1 / 2)$ : 899, 2019.

34. LIU J.R., SONG X.F., YUAN G.F., SUN X.M., LIU X., WANG S.Q. Characteristics of $\delta^{18} \mathrm{O}$ in precipitation over Eastern Monsoon China and the water vapor sources. Chinese Sci Bull, 54 (22), 3521, 2009.

35. TAKATSUKA Y., NIEKUS M.R. , HARRINGTON J., FENG S, WATKINS D., MIRCHI A., NGUYEN H., SUKOP M.C. Value of irrigation water usage in South Florida agriculture. Science of the Total Environment, 626, 486, 2018.

36. STIGTER T.Y., DILL A., RIBEIRO L., REIS E. Impact of the shift from groundwater to surface water irrigation on aquifer dynamics and hydrochemistry in a semi-arid region in the south of Portugal. Agricultural Water Management, 85 (1-2), 121, 2006.

37. LIU Z., HUANG W.C. Drought early warning in irrigation area by integrating surface water and groundwater. Paddy and Water Environment, 13 (2), 145, 2015.

38. US SALINITY LABORATORY STAFF. Diagnosis and improvement of saline and alkali soils. In: Agriculture handbook. US Dept Agriculture, USA, 1954.

39. RICHARDS L.A. Diagnosis and Improvement of Saline and Alkali Soils. Soil Science, 64, 290, 1954.

40. EATON, FRANK, M. Significance of carbonates in irrigation waters. Soil Science, 69 (2), 123, 1950.

41. WILCOX L.V. Classification and use of irrigation waters. Glycobiology, 12 (3), 229-234(6), 2002.

42. CSSRI I., GUPTA I.C. Concept of residual sodium carbonate in irrigation waters in relation to sodic hazard in irrigated soils. Curr Agric Sci, 7, 97, 1983.

43. KELLEY W.P. Use of saline irrigation water. Soil Science, $95(6), 385,1963$

44. DONEEN L.D.C. Note on water quality in agriculture. Department of water science and engineering, University of California, USA, 1964 